\title{
Ameliorative Effect of Caryopteris grata benth. Against Arsenic-Induced Enzymatic Alterations in Testis of Albino Balb/c Mice
}

\author{
Kamran Ullah", 2,4*, Sarwat Jahan², Fawad Aziz', Mian Sayed Khan', \\ Khaliq Ur Rahman ${ }^{3}$, Zafar Ali Shah ${ }^{3}$, Tanzil Ur Rahman ${ }^{4}$ \\ 'Department of Zoology, University of Swabi, Anbar, Khyber Pakhtunkhwa, Pakistan \\ ${ }^{2}$ Laboratory of Reproductive Physiology, Department of Animal Sciences, Quaid-i-Azam University, \\ Islamabad, Pakistan \\ ${ }^{3}$ Department of Chemistry, University of Swabi, Anbar, Khyber Pakhtunkhwa, Pakistan \\ ${ }^{4}$ Department of Pathology and Pathophysiology, School of Medicine, Zhejiang University, Hangzhou, China
}

Received: 13 December 2017

Accepted: 12 January 2018

\begin{abstract}
Arsenic (As) contaminates drinking water worldwide and its potential impact on human health has been studied for decades. A number of traditional medicinal plants are used to counteract arsenic's deleterious effects on humans. Phytochemical screening of Caryopteris grata revealed the presence of Quercetin, myricetin, sesquiterpenoids, and spathulenol. The present study was designed to evaluate whether the crude extract of leaves of $C$. grata inhibited arsenic-induced testicular toxicity in albino BALB/c mice. To examine the effects, mice were divided into five groups (A-E) of 6 mice each: Group A was provided with distilled water and served as a control. Group B mice were given sodium arsenite $\left(\mathrm{NaAsO}_{2}\right)$ at a dose of $10 \mathrm{mg} / \mathrm{kg}$ body weight (bw) for 10 days orally. Groups C, D, and E were treated with $\mathrm{NaAsO}_{2}$ plus graded doses of $C$. grata extract $(150,300,400 \mathrm{mg} / \mathrm{kg}$ bw), respectively. Testicular activities of antioxidant enzymes such as CAT, POD, SOD, GSH, GSR, and serum testosterone levels were significantly $(\mathrm{P}<0.05)$ decreased in Group B compared to Group A. C. grata markedly normalized $(\mathrm{P}<0.05)$ levels of CAT (0.72 and $0.46 \mathrm{U} / \mathrm{mint})$, POD (0.311 and $0.126 \mathrm{U} / \mathrm{mint})$, SOD (2.11 and $1.33 \mathrm{U} / \mathrm{mg}$ protein), GSH (0.679 and $0.284 \mu \mathrm{mol} / \mathrm{g}$ ), and GSR (216.11 and $172.25 \mathrm{nmol} / \mathrm{min} / \mathrm{mg}$ protein), along with testosterone levels $(1.18 \pm 0.017$ and $0.38 \pm 0.021 \mathrm{ng} / \mathrm{ml})$ at the tested doses, respectively. Conclusively, the crude extract of $C$. grata leaves may inhibit both arsenic's adverse effect on male reproductive hormones and testicular oxidative damage in mice.
\end{abstract}

Keywords: Caryopteris grata Benth. antioxidant, arsenic, toxicity, testis

*e-mail: kamranqau84@gmail.com, kamranullah@uoswabi.edu.pk 


\section{Introduction}

According to the World Health Organization (WHO), about $15 \%$ of couples fail to conceive with regular unprotected intercourse over a year [1]. Among the male population, approximately 1:20 is affected by male infertility [2]. Current evidence suggests a role played by the wide range of genetic, environmental, and lifestyle risk factors acting alone or in combination with the pathogenesis of male infertility.

Arsenic (As), a natural and ubiquitously distributed environmental contaminant, was found to be associated with various developmental and reproductive abnormalities. Human exposure to high levels of arsenic could result in severe metabolic disorders such as diabetes, gastrointestinal tract disorders, and cardiovascular diseases [3-4]. Previous studies have shown that arsenic toxicity involves oxidative damage primarily by the interaction of arsenic with protein thiols, a vital component of redox-sensitive proteins in redox signaling and control pathways [5-6]. Several studies have shown that liver is the primary arsenic metabolizing organ. Metabolic conversion of arsenic into methylated form yields mono, di, and trimethylated arsenic, which exhibited various toxic effects compared to the parental compounds [7].

Arsenic exposure dramatically inhibited the activity of first lines of defense mechanisms provided by antioxidant enzymes like superoxide dismutase (SOD), catalase (CAT), peroxidase (POD), and glutathione reductase (GSR), and increased production of oxygen and oxygenderived free radicals known as reactive oxygen species [8-9]. In semen, antioxidant enzymes such as SOD, CAT, and GSH/GPX might contribute to antioxidant defense mechanisms against reactive oxygen species (ROS) [10]. Under pathological conditions, uncontrolled production of ROS disrupts the integrity of the sperm DNA, causing defective sperm function [11]. Depletion of antioxidant enzymes CAT, POD, and SOD significantly lowers steroidogenic enzymes by triggering levels of ROS and lipid peroxidation in Leydig cells [8]. In mammals, the lack of a key enzyme glutathione peroxidase 5 (GPx5) correlates with sperm DNA damage, finally a potential risk factor for the development of abnormal human embryos [12]. Deletion of a key enzyme glutathione peroxidase 5 (GPx5) in male mice mated with wildtype female mice induces oxidative stress along with the occurrence of miscarriage and birth defects [10]. Sodium arsenite $\mathrm{NaAsO}_{2}(10 \mathrm{mg} / \mathrm{kg})$ treatment significantly raises arsenic bioaccumulation, DNA fragmentation, and oxidative stress in mice testes, along with an alteration in cytoarchitecture of the organs [13]. In Taiwan, enhanced erectile dysfunction (ED) has been reported in an arsenicendemic area compared to the non-endemic area [14]. A significant decrease in epididymal sperm counts and testicular weights was reported in male mice exposed to 20 or $40 \mathrm{mg} / \mathrm{l}$ sodium arsenite [15]

Almost $15-25 \%$ of couples seek medical advice to increase the rate of fertilization and successful pregnancy.
Numerous plant extracts and their active constituents have been reported to improve male fertility. Bajijiasuis isolated from Morinda officinalis F.C. modulates hormone levels and protects the DNA of human sperm from $\mathrm{H}_{2} \mathrm{O}_{2}$ damage [16]. Aerial parts of Ipomea aquatica extracts counteract oxidative stress and associated toxic manifestations by declining $\mathrm{NaAsO}_{2}$-mediated generation of ROS [13]. Caryopteris grata (Verbenaceae) native to Pakistan sub-Himalayan tracts (e.g., Margalla Hills, Haripur, Abbottabad, and lower Murree Hills) has an evergreen shrub with erect or arching stems, 2-4 feet high with pale brown bark. Young shoots, inflorescence, and petioles are arrayed with dense usually purplish or violet tomentum, often colored on one side. Leaves usually opposite or whorled and often entire, oblonglanceolate, acuminate usually caudate, crenate-serrate or subentire, base rounded or cuneate, soft, membranous, and with pale pubescent on both surface; lateral nerves 5-9 pairs. Previous studies have revealed the presence of Quercetin, myricetin, and contents of biologically active essential oil, e.g., sesquiterpenoids and spathulenol in the genus Caryopteris grata [17]. In rats quercetin treatment markedly increases plasma and testicular testosterone concentration [18]. Quercetin and myricetin also protect DNA damage against hydrogen peroxide $\left(\mathrm{H}_{2} \mathrm{O}_{2}\right)$ [19]. Therefore, our objective was to study the antitoxic effect of the leaves of $C$. grata against arsenic-induced oxidative stress in testicular tissues of mice.

\section{Materials and Methods}

\section{Plant Collection and Extract Preparation}

Caryopteris grata (Verbenaceae) plants were collected and identified, and a specimen was submitted to the Herbarium of Pakistan, Quaid-i-Azam University Islamabad, Pakistan. Plant leaves were shade-dried for two weeks, mechanically chopped, and ground. One kg fresh powder of C. grata (leaves) was taken, macerated with methanol for another two weeks at room temperature, and the solvent was filtered using ordinary filter paper. Filtrates were re-filtered using Whatmann filter paper No. 45 . The process was repeated thrice and filtrates were combined. Finally, $25 \mathrm{~g}$ crude methanolic extract (free of solvent) of $C$. grata was obtained by concentrating the filtrates through a vacuum evaporator [20].

\section{Animals and Treatment}

The experimental groups consisted of a total of 30 adult albino BALB/c mice $(35 \pm 2 \mathrm{~g})$, taken from the National Institute of Health (NIH) Islamabad, Pakistan. The animals were kept in plastic cages ( 3 mice per cage) at room temperature $\left(25 \pm 3^{\circ} \mathrm{C}\right)$ on a $12 / 12$-h light/dark cycle for two weeks. The mice were fed a standard diet and had free access to water. The experimental protocol for animal care and laboratory use was duly approved by the ethical committee of Quaid-i-Azam University 
Islamabad, Pakistan. The mice were divided into 5 groups, each comprising 6 animals. Group A (control) had free access to food and distilled water. Group B received $10 \mathrm{mg} / \mathrm{kg}$ bw of sodium arsenite $\left(\mathrm{NaAsO}_{2}\right)$ dissolved in $3.8 \mathrm{ml}$ of water [13]. Group C mice were treated with $10 \mathrm{mg} / \mathrm{kg}$ of sodium arsenite plus C. grata extract $(150 \mathrm{mg} / \mathrm{kg} \mathrm{bw})$. Groups D and E were given $300 \mathrm{mg} / \mathrm{kg}$ bw and $400 \mathrm{mg} / \mathrm{kg}$ bw $C$. grata extracts, respectively, along with sodium arsenite treatment as described above [21]. All the animals were under treatment for 10 days [13]. The plant extract was administered orally by gastric intubation using a syringe or feeding tubes once daily. After the last treatment, the animals were kept on normal feed for at least 48 hours, decapitated, and the arterio-venous blood was collected. The serum was separated and stored at $-20^{\circ} \mathrm{C}$ until analyzed. Testis excised immediately were weighed, treated with liquid nitrogen, and stored at $-70^{\circ} \mathrm{C}$ for further biochemical studies.

\section{Assessing Tissue Biochemical Studies}

Homogenization of testicular tissues $(70 \mathrm{mg})$

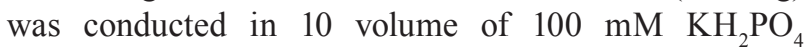
(potassium dihydrogen phosphate) buffer containing $1 \mathrm{mM}$ EDTA, having $\mathrm{pH} 7.4$ followed by centrifugation at $12,000 \times \mathrm{g}$ for $30 \mathrm{~min}$ at $4^{\circ} \mathrm{C}$ The supernatant was collected for further analysis.

\section{Catalase (CAT) Assay}

CAT assay was conducted by following the Chance and Maehly method with some modification [22]. The reaction solution of CAT activities is composed of $0.4 \mathrm{ml}$ of $5.9 \mathrm{mM} \mathrm{H}_{2} \mathrm{O}_{2}, 0.1 \mathrm{ml}$ enzyme extract and $2.5 \mathrm{ml}$ of $50 \mathrm{mM}$ phosphate buffer $(\mathrm{pH} 5.0)$. After one minute, an absorbance of the reaction solution was checked at $240 \mathrm{~nm}$, and changes were noted. One unit of CAT activity was defined as an absorbance change of 0.01 as units/min.

\section{Peroxidase (POD) Assay}

POD assay was measured by using Chance and Maehly protocol with some modification [22]. $3 \mathrm{ml}$ POD reaction solution is composed of $2.5 \mathrm{ml}$ of $50 \mathrm{mM}$ phosphate buffer ( $\mathrm{pH} 5.0$ ), $0.1 \mathrm{ml}$ of $20 \mathrm{mM}$ guaiacol, $0.3 \mathrm{ml}$ of $40 \mathrm{mM} \mathrm{H}_{2} \mathrm{O}_{2}$, and $0.1 \mathrm{ml}$ enzyme extract. After one minute, an absorbance of the reaction solution was determined at $470 \mathrm{~nm}$ and changes were noted. One unit of POD activity was defined an absorbance change of 0.01 as units/min.

\section{Superoxide Dismutase (SOD) Assay}

Kakkar et al. [23] protocol was used for determining SOD assay. Reaction mixture is composed of $0.1 \mathrm{ml}$ of phenazine methosulphate $\left(\mathrm{C}_{14} \mathrm{H}_{14} \mathrm{~N}_{2} \mathrm{O}_{4} \mathrm{~S}\right)$ $(186 \mu \mathrm{M}), 1.2 \mathrm{ml}$ of sodium pyrophosphate $\left(\mathrm{Na}_{4} \mathrm{P}_{2} \mathrm{O}_{7}\right)$ buffer $(0.052 \mathrm{mM}, \mathrm{pH} 7.0), 0.3 \mathrm{ml}$ of supernatant after centrifugation $(1500 \times \mathrm{g}, 10 \mathrm{~min}$ followed by $10,000 \times \mathrm{g}, 15 \mathrm{~min})$ of $10 \%$ testicular homogenate was added to the reaction mixture. The addition of $0.2 \mathrm{ml}$ of NADH $(780 \mu \mathrm{M})$ initiates the enzyme reaction. The reaction was stopped after $1 \mathrm{~min}$ by adding $1 \mathrm{ml}$ of glacial acetic acid. Finally, a total amount of chromogen formed was measured at $560 \mathrm{~nm}$ by recording its color intensity. Results are expressed in units/mg protein.

\section{Reduced Glutathione (GSH) Assay}

The assay was performed by following Jollow et al. [24] protocol. $1.0 \mathrm{ml}$ sample of $10 \%$ homogenate was precipitated with $1.0 \mathrm{ml}$ of (4\%) sulfosalicylic acid $\left(\mathrm{C}_{7} \mathrm{H}_{6} \mathrm{O}_{6} \mathrm{~S}\right)$. After precipitation, the samples were kept at $4^{\circ} \mathrm{C}$ for $1 \mathrm{~h}$ and then followed by centrifugation at $1200 \times \mathrm{g}$ for $20 \mathrm{~min}$ at $4^{\circ} \mathrm{C}$. Assay mixture of $3.0 \mathrm{ml}$ contained $0.1 \mathrm{ml}$ filtered aliquot, $0.2 \mathrm{ml}$ DTNB (5, 5-dithiobis-2-nitrobenzoic acid), (100 mM), and $2.7 \mathrm{ml}$ phosphate buffer $(0.1 \mathrm{M}, \mathrm{pH} 7.4)$. The yellow color of the mixture was developed, read immediately at $412 \mathrm{~nm}$ on a Smart SpecTM plus spectrophotometer, and expressed as $\mu \mathrm{M}$ GSH/g tissue.

\section{Glutathione Reductase (GSR) Assay}

GSR assay was estimated by the Carlberg and Mannervi method [25]. The reaction solution is composed of $1.65 \mathrm{ml}$ phosphate buffer: (0.1 M, $\mathrm{pH}$ 7.6), $0.1 \mathrm{ml}$ NADPH $(0.1 \mathrm{mM}), 0.1 \mathrm{ml}$ EDTA $(0.5 \mathrm{mM}), 0.05 \mathrm{ml}$ oxidized glutathione $(1 \mathrm{mM})$, and $0.1 \mathrm{ml} 10 \%$ homogenate in a total volume of $2 \mathrm{ml}$. Enzyme activity was determined at $25^{\circ} \mathrm{C}$ by recording the disappearance of NADPH at $340 \mathrm{~nm}$ and was calculated as nM NADPH oxidized $/ \mathrm{min} / \mathrm{mg}$ protein using a molar extinction coefficient of $6.22 \times 103 / \mathrm{M} \mathrm{cm}$.

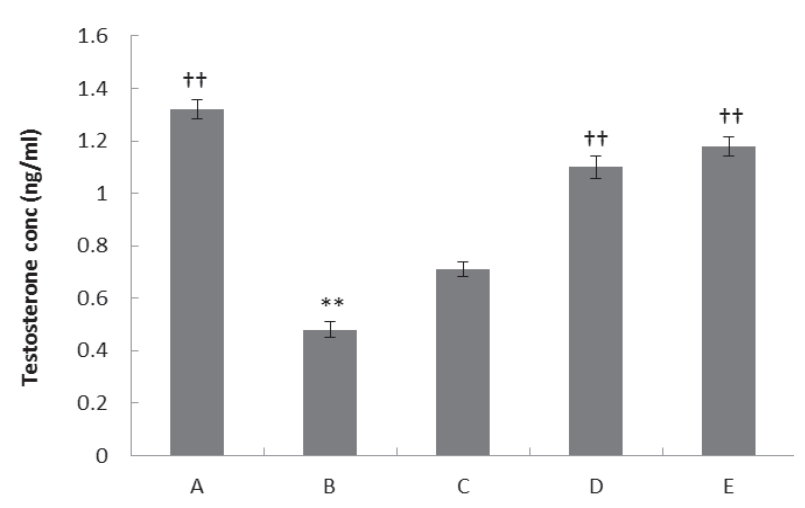

Fig. 1. Comparison of relative testicular weights $(n=6)$ :

$\mathrm{A}=$ Control

$\mathrm{B}=\mathrm{NaAsO}_{2}(10 \mathrm{mg} / \mathrm{kg})$

$\mathrm{C}=$ C. grata extract $(150 \mathrm{mg} / \mathrm{kg})+\mathrm{NaAsO}_{2}$

$\mathrm{D}=C$. grata extract $(300 \mathrm{mg} / \mathrm{kg})+\mathrm{NaAsO}_{2}$

$\mathrm{E}=C$. grata extract $(400 \mathrm{mg} / \mathrm{kg})+\mathrm{NaAsO}_{2}$

** significance from control group $(\mathrm{P}<0.05)$

$\dagger \dagger$ significance from the $\mathrm{NaAsO}_{2}$ group $(\mathrm{P}<0.05)$ 


\section{Testosterone Assay}

Testosterone concentrations were measured by using specific EIA. The EIA kits were purchased from Biocheck, Inc, Burlingame, CA, USA.

\section{Statistical Analysis}

All the recorded values were expressed in mean \pm SEM. Data were analyzed using one-way analysis of variance (ANOVA) carried by computer software Graph Pad Prism version 5.0 (California corporation, USA) for testosterone and SPSS 11.0 software (SPSS, Inc., Chicago, IL) for antioxidant enzymes. Among the various treatments, the level of significance was $\mathrm{P}<0.05$.

\section{Results and Discussion}

\section{Testicular Weight}

The relative testicular weights (Fig. 1) were significantly $(\mathrm{P}<0.05)$ decreased in $\mathrm{NaAsO}_{2}$-treated mice (Group B) compared to control (Group A). Oral administration of $C$. grata extracts (300 and $400 \mathrm{mg} / \mathrm{kg} \mathrm{bw}$ ) in Groups D and E markedly normalized the distorted testicular weight toward the normal against $\mathrm{NaAsO}_{2}$-induced toxicity.

\section{Biochemical Assays}

\section{Effects on CAT, POD, and SOD}

Table 1 shows the effect of various doses of $C$. grata extract against $\mathrm{NaAsO}_{2}$ intoxication on tissue levels of CAT, POD, and SOD. Activities of CAT, POD, and SOD were significantly reduced $(\mathrm{P}<0.05)$ in testicular tissues of Group B compared to Group A. Oral administration of $C$. grata extracts $(150,300$, and $400 \mathrm{mg} / \mathrm{kg} \mathrm{bw}$ ) in Groups C, D, and E significantly increased $(\mathrm{P}<0.05)$ activities of $\mathrm{POD}$ and $\mathrm{SOD}$ in a dose-dependent way compared to Group B. On the other hand, activity of CAT was significantly $(\mathrm{P}<0.05)$ recovered at doses of 300 and $400 \mathrm{mg} / \mathrm{kg}$ bw compared to the $\mathrm{NaAsO}_{2}$ group.

\section{Effect on GSH and GSR}

Administering $\mathrm{NaAsO}_{2}$ (Group B) significantly reduced $(\mathrm{P}<0.05)$ activities of GSH and GSR in testicular tissues of mice compared to the control (Group A), as shown in Table 1. Co-treatment of sodium arsenite and plant extract in Groups C, D, and E ameliorate activity of GSH significantly $(\mathrm{P}<0.05)$ compared to Group B in a dose-dependent manner. GSR activity was significantly $(\mathrm{P}<0.05)$ restored to the normal at doses of 300 and 400 $\mathrm{mg} / \mathrm{kg}$ body weight.

\section{Effect of Extract on Serum Level of Testosterone}

The protective effects of various doses of C. grata methanolic extract on serum levels of testosterone are shown in Fig. 2. The concentration of serum testosterone were significantly $(\mathrm{P}<0.05)$ decreased in mice treated with $\mathrm{NaAsO}_{2}$ (Group B), compared to control Group A. However, co-administration of graded doses of methanolic extract of C. grata leaves in Groups C, D, and $\mathrm{E}$ offered marked protection against $\mathrm{NaAsO}_{2}$ intoxication, resulting in a significant $(\mathrm{P}<0.05)$ increase in the serum levels of testosterone.

Recently, epidemiologic studies have suggested that oxidative stress may be the major cause of male reproductive failure. In populations of human spermatozoa the majority of DNA damage is associated with the onset of oxidative stress [26]. Arsenic (As), a well-known endocrine disruptor, induces oxidative stress by triggering ROS [2]. Electron leakage from the sperm mitochondria is supposed to be the main source of ROS [27]. Excessive production of ROS by sperm

Table 1. Effects of various doses of crude methanolic extract of C. grata on the activity of CAT, POD, SOD, GSH, and GSR in testis of mice (all values are mean $\pm S E, n=6$ ).

\begin{tabular}{|c|c|c|c|c|c|c|}
\hline Group & Treatment & CAT (U/mint) & POD (U/mint) & $\begin{array}{c}\text { SOD } \\
\text { (U/mg protein) }\end{array}$ & $\begin{array}{c}\mathrm{GSH} \\
(\mu \mathrm{mol} / \mathrm{g})\end{array}$ & $\begin{array}{c}\text { GSR } \\
\text { (nmol/min } / \mathrm{mg} \\
\text { protein) }\end{array}$ \\
\hline A & Control & $1.16 \pm 0.033 \dagger \dagger$ & $0.387 \pm 0.020 \dagger \uparrow$ & $2.19 \pm 0.051 \dagger \dagger$ & $0.673 \pm 0.025 \dagger \dagger$ & $221.13 \pm 3.14 \dagger \dagger$ \\
\hline B & $\mathrm{NaAsO}_{2} 10 \mathrm{mg} / \mathrm{kg}$ & $0.46 \pm 0.020^{* *}$ & $0.126 \pm 0.019 * *$ & $1.33 \pm 0.034^{* *}$ & $0.284 \pm 0.023 * *$ & $172.25 \pm 2.10 * *$ \\
\hline $\mathrm{C}$ & $\begin{array}{c}150 \mathrm{mg} / \mathrm{kg} \mathrm{C.} \mathrm{grata} \text { extract }+ \\
\mathrm{NaAsO}_{2}\end{array}$ & $0.47 \pm 0.041 * *$ & $0.187 \pm 0.043 \dagger \dagger$ & $1.83 \pm 0.092 \dagger \dagger$ & $0.587 \pm 0.020 \dagger \uparrow$ & $182.28 \pm 2.98 * *$ \\
\hline $\mathrm{D}$ & $\begin{array}{c}300 \mathrm{mg} / \mathrm{kg} \mathrm{C} \text {. grata extract }+ \\
\mathrm{NaAsO}_{2}\end{array}$ & $0.68 \pm 0.038 * \dagger$ & $0.311 \pm 0.037 \dagger \dagger$ & $2.02 \pm 0.047 \dagger \dagger$ & $0.591 \pm 0.043 \dagger \dagger$ & $213.63 \pm 3.76 \dagger \dagger$ \\
\hline $\mathrm{E}$ & $\begin{array}{c}400 \mathrm{mg} / \mathrm{kg} \mathrm{C} \text {. grata extract }+ \\
\mathrm{NaAsO}_{2}\end{array}$ & $0.72 \pm 0.057 \dagger \dagger$ & $0.289 \pm 0.029 \dagger \dagger$ & $2.11 \pm 0.060 \dagger \dagger$ & $0.679 \pm 0.030 \dagger \dagger$ & $216.11 \pm 3.09 \dagger \dagger$ \\
\hline
\end{tabular}

** significance from control group $(\mathrm{P}<0.05)$

$\dagger$ significance from the $\mathrm{NaAsO}_{2}$ group $(\mathrm{P}<0.05)$ 


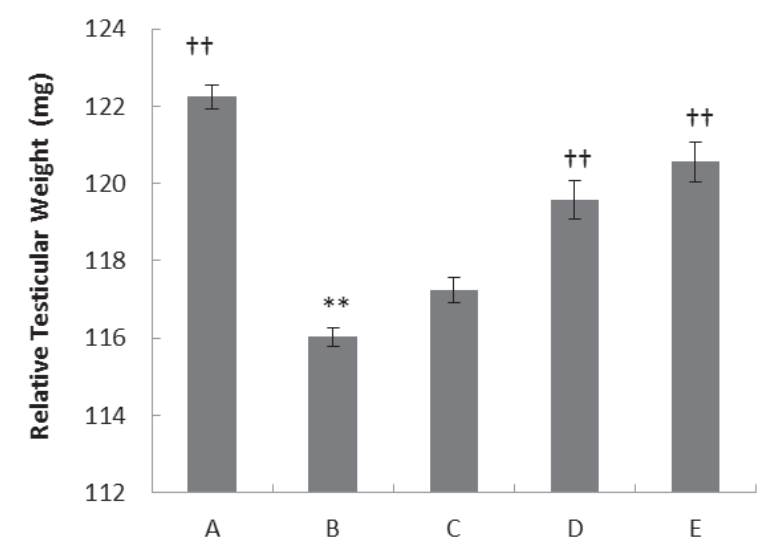

Fig. 2. Comparison of relative serum testosterone levels $(n=6)$ : $\mathrm{A}=$ Control

$\mathrm{B}=\mathrm{NaAsO}_{2}(10 \mathrm{mg} / \mathrm{kg})$

$\mathrm{C}=C$. grata extract $(150 \mathrm{mg} / \mathrm{kg})+\mathrm{NaAsO}_{2}$

$\mathrm{D}=C$. grata extract $(300 \mathrm{mg} / \mathrm{kg})+\mathrm{NaAsO}_{2}$

$\mathrm{E}=C$. grata extract $(400 \mathrm{mg} / \mathrm{kg})+\mathrm{NaAsO}_{2}$

$* *$ significance from control group $(\mathrm{P}<0.05)$

$\dagger \dagger$ significance from the $\mathrm{NaAsO}_{2}$ group $(\mathrm{P}<0.05)$

mitochondria intensifies DNA damage in the sperm nucleus by deteriorating the epididymal antioxidant enzymes CAT, SOD, GSH and glutathione peroxidase 5 (GPx5), which in turn significantly increases levels of miscarriage, the development of abnormal human embryos, and childhood disease in offspring of men displaying high levels of DNA damage in their spermatozoa $[12,28]$.

In the present study, in addition to the reduction in relative testicular weight of $\mathrm{NaAsO}_{2}$-treated mice, testicular toxicity is reflected by a significant $(\mathrm{P}<0.05)$ decrease in the number of antioxidant enzymes such as CAT, POD, SOD, GSH, and GSR. The decreased testicular weight in $\mathrm{NaAsO}_{2}$-treated mice is suggested to be related to the oxidative damage. The said findings are in accordance with the previously reported results in rats that repeated injections of arsenic trioxide reduce hepatic levels of CAT, SOD GSH, and GSR, and induces the accumulation of arsenic in tissue [29]. Das et al. reported that in animals, sodium arsenite treatment at a dose of $10 \mathrm{mg} / \mathrm{kg}$ b.w for 10 days significantly decreases $(\mathrm{p}<0.01)$ hepatic and renal antioxidant enzymes like superoxide dismutase, catalase, glutathione-S-transferase, glutathione peroxidase, and glutathione reductase [30]. Testicular steroidogenic enzymes $\Delta 5,3 \beta$-HSD and $17 \beta$-HSD play a key regulatory role in testosterone biosynthesis. In rats, $\mathrm{NaAsO}_{2}$ treatment lowered plasma and intratesticular concentrations of testosterone in a dose-dependent manner with the inhibition of testicular androgenesis enzymes [31-32]. Jahan et al. [18] proposed a significant decrease in plasma and testicular testosterone levels in rats treated with arsenic. These findings are in agreement with our present results in mice that sodium arsenite treatment $(10 \mathrm{mg} / \mathrm{kg}$ b.w $)$ significantly $(\mathrm{P}<0.05)$ decreases serum levels of testosterone. Adult rats treated with $\mathrm{NaAsO}_{2}$ resulted a decrease in paired testicular weights, and inhibited androgen production along with a decline in epididymal sperm count, plasma LH, FSH, testosterone, and testicular testosterone concentrations with an increased plasma concentration of corticosterone [4].

Currently, several herbal drugs with free radical scavenging potential are widely used as antioxidants. Following the research lines of Caryopteris grata that revealed the presence of Quercetin, myricetin, sesquiterpenoids, and spathulenol, we undertook the present study to examine the protective effects of the plant leaves against testicular toxicity caused by $\mathrm{NaAsO}_{2}$ in male mice. Graded doses of $C$. grata cotreatment markedly normalized testicular antioxidant enzymes (CAT, POD, SOD, GSH, GSR) to the control along with a significant $(\mathrm{P}<0.05)$ increase in serum levels of testosterone. It can therefore be postulated that the plant leaves may be used as a potential therapeutic drug against arsenic-induced reproductive toxicity. However, larger scale and molecular studies are needed to isolate and purify their bioactive compounds for further investigation. Our findings are corroborated with a recently reported similar type of work that Bajijiasuis isolated from Morinda officinalis F.C. modulates hormone levels and protects the DNA of human sperm from $\mathrm{H}_{2} \mathrm{O}_{2}$ damage [16]. An in vitro study reported that ethanolic extract of Tulbaghia violacea significantly increased LH-induced testosterone secretion compared to control [33]. In bull and rat Leydig cells, Basella alba extracts significantly enhanced testosterone production in a dose-dependent manner [34]. Seed extract of Moringa oleifera (Sajina) with co-treatment in arsenic-treated female rats was capable of suppressing oxidative stress and restoring activities of SOD and CAT significantly [35].

\section{Conclusions}

In conclusion, the plant product might be efficacious in inducing testicular androgenesis enzymes against $\mathrm{NaAsO}_{2}$ intoxication and has the potential to elevate serum testosterone levels in mice. However, further work is needed to isolate and purify their bioactive compounds and elucidate its possible mechanism of action.

\section{Acknowledgements}

This study was supported by the Higher Education Commission, Pakistan (project No. 1829 to Ullah K). The authors also want to thank the National Institute of Health, Islamabad for providing the experimental animals.

\section{Conflict of Interest}

The authors declare that no conflict of interest exists. 


\section{References}

1. DAVAR R., SEKHAVAT L., NASERZADEH N. Semen parameters of non-infertile smoker and non-smoker men. J. med life. 5 (4), 465, 2012.

2. AITKEN R.J., SMITH T.B., JOBLING M.S., BAKER M.A., DE IULIIS G.N. Oxidative stress and male reproductive health. Asian J. androl. 16 (1), 31, 2014.

3. PAUL S., CHAKRABORTY S., ALI M.N., RAY D.P. Arsenic distribution in environment and its bioremediation: A review. Int J. Agri Envi Biotechnol. 8 (1), 189, 2015.

4. JOMOVA K., JENISOVA Z., FESZTEROVA M., BAROS S., LISKA J., HUDECOVA D., VALKO M. Arsenic: toxicity, oxidative stress and human disease. J. App Toxicol. 31 (2), 95, 2011.

5. JOMOVA K., VALKO M. Advances in metal-induced oxidative stress and human disease. Toxicol. 283 (2), 65, 2011.

6. HANSEN J.M., ZHANG H., JONES D.P. Differential oxidation of thioredoxin-1, thioredoxin-2, and glutathione by metal Ions. Free Radic Biol. Med. 40, 138, 2006.

7. EL-DEMERDASH F.M., YOUSEF M.I., RADWAN F.M. Ameliorating effect of curcumin on sodium arseniteinduced oxidative damage and lipid per oxidation in different rat organs. Food Chem Toxicol. 47 (1), 249, 2009.

8. AGARWAL A., VIRK G., ONG C., DU PLESSIS S.S. Effect of oxidative stress on male reproduction. World $\mathrm{J}$ Mens Health. 32 (1), 1, 2014.

9. POWERS S.K., JACKSON M.J. Exercise-induced oxidative stress: cellular mechanisms and impact on muscle force production. Physiol rev. 88 (4), 1243, 2008.

10. CHABORY E., DAMON C., LENOIR A., KAUSELMANN G., KERN H., ZEVNIK B. Epididymis seleno-independent glutathione peroxidase 5 maintains sperm DNA integrity in mice. J. Clin. Invest. 119 (7), 2074, 2009.

11. AITKEN R., DE IULIIS G. On the possible origins of DNA damage in human spermatozoa. Molecular human reproduction. Basic Sci. Reprod. Med. 16, 3, 2010.

12. GHARAGOZLOO P., AITKEN R.J. The role of sperm oxidative stress in male infertility and the significance of oral antioxidant therapy. Human. Reprod. 26 (7), 1628, 2011.

13. DUA T.K., DEWANJEE S., GANGOPADHYAY M., KHANRA R., ZIA-UL-HAQ M., DE FEO V. Ameliorative effect of water spinach, Ipomea aquatica (Convolvulaceae), against experimentally induced arsenic toxicity. J. Transl. Med.13 (1), 81, 2015

14. MAZUMDER D.G. Health Effects Chronic Arsenic Toxicity. Handbook. Arsenic Toxicol. 137, 2015.

15. MATHUR N., PANDEY G., JAIN G.C. Male reproductive toxicity of some selected metals: A review. J. Biol Sci. 10 (5), 396, 2010.

16. WU Z.Q., CHEN D.L., LIN F.H., LIN L., SHUAI O., QI L.K., ZHANG P. Effect of bajijiasu isolated from Morinda officinalis $\mathrm{FC}$ how on sexual function in male mice and its antioxidant protection of human sperm. J. Ethnopharmacol. 164, 283, 2015.

17. UPADHYAYA K., DIXIT V., PADALIA R., MATHELA C. Chemical composition of the essential oil of Caryopteris grata Benth. J. Essent Oil Res. 21 (1), 69, 2009.

18. JAHAN S., IFTIKHAR N., ULLAH H., RUKH G., HUSSAIN I. Alleviative effect of quercetin on rat testis against arsenic: a histological and biochemical study. Sys Bio. Reprod Med. 61 (2), 89, 2015.
19. WILMS L.C., HOLLMAN P.C., BOOTS A.W. KLEINJANS J.C. Protection by quercetin and quercetinrich fruit juice against induction of oxidative DNA damage and formation of BPDE-DNA adducts in human lymphocytes. Mutat Res/Genet Toxicol. Env Mutat. 582 (1), 155, 2005.

20. SHAH N.A., KHAN M.R., NADHMAN A. Antileishmanial, Toxicity, and Phytochemical Evaluation of Medicinal Plants Collected from Pakistan. Biomed. Res. Int. 2014; 384204-384207 doi: 10.1155/2014/384204.

21. TADESSE W.T., HAILU A.E., GURMU A.E., MECHESSO A.F. Experimental assessment of antidiarrheal and antisecretory activity of $80 \%$ methanolic leafextract of Zehneria scabra in mice. BMC Complement. Altern. Med. 14 (1), 460, 2014.

22. CHANCE B., MAEHLY A. Assay of catalases and peroxidases. Methods. Enzymol. 2, 764, 1995.

23. KAKKAR P., DAS B., VISWANATHAN P. A modified spectrophotometric assay of superoxide dismutase. Indian J. Biochem. Biophys. 21, 130, 1948.

24. JOLLOW D., MITCHELL J., ZAMPAGLIONE N.A., GILLETTE J. Bromobenzene-induced liver necrosis. Protective role of glutathione and evidence for 3 , 4-bromobenzene oxide as the hepatotoxic metabolite. Pharmacol. 11 (3), 151, 1974.

25. CARLBERG I., MANNERVIK E.B. Glutathione level in rat brain. J. Biol. Chem. 250, 4475, 1975.

26. TREMELLEN K. Oxidative stress and male infertility - a clinical perspective. Human Reprod. Update. 14 (3), 243, 2008.

27. KOPPERS A.J., DE IULIIS G.N., FINNIE J.M., MCLAUGHLIN E.A., AITKEN R.J. Significance of mitochondrial reactive oxygen species in the generation of oxidative stress in spermatozoa. J. Clin. Endocrinol. Metab. 93 (8), 3199, 2008.

28. AITKEN R.J., DE IULIIS G.N., MCLACHLAN R.I. Biological and clinical significance of DNA damage in the male germ line. Int. J. Androl. 32 (1), 46, 2009.

29. ZHANG W., XUE J., GE M., YU M., LIU L., ZHANG Z. Resveratrol attenuates hepatotoxicity of rats exposed to arsenic trioxide. Food Chem. Toxicol. 51, 87, 2013.

30. DAS A.K., BAG S., SAHU R., DUA T.K., SINHA M.K., GANGOPADHYAY M. Protective effect of Corchorus olitorius leaves on sodium arsenite-induced toxicity in experimental rats. Food Chem. Toxicol. 48 (1), 326, 2010.

31. GHOSH P., BISWAS N., GHOSH D. Effect of lithium chloride on testicular steroidogenesis and gametogenesis in immature male rats. Acta. endocrinol. 124 (1), 76, 1991.

32. ADIL M., VISNAGRI A., KUMAR V. S., KANDHARE A. D., GHOSH P., BODHANKAR S. L. Protective effect of naringin on sodium arsenite induced testicular toxicity via modulation of biochemical perturbations in experimental rats. Pharmacol. 5 (222), 234, 2014.

33. EBRAHIM M., POOL E.J. The effect of Tulbaghia violacea extracts on testosterone secretion by testicular cell cultures. J. Ethnopharmacol. 132 (1), 359, 2010.

34. DESHMUKH S.A., GAIKWAD D.K. A review of the taxonomy, ethnobotany, phytochemistry and pharmacology of Basella alba (Basellaceae). 2013.

35. CHATTOPADHYAY S., MAITI S., MAJI G., DEB B., PAN B., GHOSH D. Protective role of Moringa oleifera (Sajina) seed on arsenic-induced hepatocellular degeneration in female albino rats. Biol. Trace. Elem. Res. 142 (2), 200, 2011. 